\title{
Piracy Challenges in the Gulf of Guinea along the Coast of Ghana, Togo, Benin and Nigeria in the Midst of Its Oil Find-A Case Study of Ghana
}

\author{
Nana Raymond Lawrence Ofosu-Boateng \\ College of Transport and Communications, Shanghai Maritime University, Shanghai, China \\ Email: boatnana@gmail.com
}

How to cite this paper: Ofosu-Boateng, N.R.L. (2018) Piracy Challenges in the Gulf of Guinea along the Coast of Ghana, Togo, Benin and Nigeria in the Midst of Its Oil Find-A Case Study of Ghana. Open Journal of Social Sciences, 6, 189-203.

https://doi.org/10.4236/jss.2018.67015

Received: June 3, 2018

Accepted: July 28, 2018

Published: July 31, 2018

Copyright $\odot 2018$ by author and Scientific Research Publishing Inc. This work is licensed under the Creative Commons Attribution International License (CC BY 4.0).

http://creativecommons.org/licenses/by/4.0/

\begin{abstract}
Maritime piracy has influenced global economic development, as shown in the case of Somalia. Through modelling the shipping demands and volumes of shipping, which require re-routing, leading to efficiency loss, it has shown that there is a substantial economic loss as a result of maritime piracy. Moreover, there are direct costs to the immediate piracy victims, where crews may be injured or killed; ships and cargoes may be stolen; and companies may experience higher operating costs and higher insurance costs. The indirect costs of piracy are also significant, especially in relation to humanitarian considerations. This paper discusses maritime piracy in the scope of the Gulf of Guinea and the coast of Ghana. The discussion, the modus operandi of piracy, is within both the Gulf of Guinea and the coast of Ghana. There is a discussion and provision of statistics relating to piracy acts along the coast of Ghana, Nigeria, Togo, and Benin. Next, a discussion is held regarding piracy concerns in relation to the role of the Ghana Navy, Vessel Traffic Management (VTMS), and the security of Ghana. Following this, a discussion is held regarding the joint military exercises that are held with the Ghana military along the coast of Ghana and the role of China. Following this, there is a discussion of the policy and maritime framework based on maritime transportation and maritime security along the Gulf of Guinea.
\end{abstract}

\section{Keywords}

Benin, China, Ghana, Gulf of Guinea, Maritime Piracy, Maritime Transportation, Maritime Security, Nigeria, Togo

\section{Introduction}

It is widely recognised that current frameworks on a domestic, regional, and in- 
ternational level are not adequate at counteracting maritime piracy, nor are they unified in their approach to address modern piracy. Maritime piracy has a significant impact on tourism, shipping, and manufacturing industries, prompting governments to conclude that maritime piracy is a serious problem because it influences security and safety [1]. However, contrary to some suggestions, maritime piracy attacks are not always random events and incidences may increase based on the type of vessel and flag of registry [2].

Other research has shown that maritime piracy is economically driven because the primary goal of most pirates is to increase their profit. Between 2003 and 2008, most piracy attacks occurred around the Gulf of Aden and Horn of Africa. Economically driven piracy is enabled because a significant amount of cargo is shipped by sea and these areas represent congested bottlenecks [3] [24]. Since ship owners tend to focus on having minimal operating costs, it is not uncommon for these ships to have skeleton crews, increasing the likelihood of piracy. Moreover, in favour of increased security monitoring on land, there is less security monitoring on water, further increasing the likelihood of piracy. Other factors include the increase in small arms availability (providing weapons for conducting piracy) and the willingness of ship owners to pay ransom demands (providing incentives for piracy) [4].

Maritime piracy has influenced global economic development, as shown in the case of Somalia. Through modelling the shipping demands and volumes of shipping, which require re-routing, leading to efficiency loss, [4] have shown that there is a substantial economic loss as a result of maritime piracy. Moreover, there are direct costs to the immediate piracy victims, where crews may be injured or killed; ships and cargoes may be stolen; and companies may experience higher operating costs and higher insurance costs. The indirect costs of piracy are also significant, especially in relation to humanitarian considerations. For example, if a ship containing cargo for a humanitarian group is hijacked and its cargo is stolen, such as relief products, the victims extend to include those that would have benefited from the provision of relief needed for survival (such as food). Therefore, in the case of Somalia and Nigeria, living conditions, which are already fragile due to the poverty of the regions, are worsened by piracy [5]. It is in the interest of all littoral states to effectively protect their coastline. Most of these states have no efficient institutions to undertake the required security necessary to safeguard their waters. According to [25], there are eight variables that cause pirates in the Gulf of Guinea. These variables consists of cultural acceptability, a political environment that is permissive, deficient security, weakness in the jurisdictional and legal system, poorly resourced security agencies, conflict disorder, good and acceptable geography and the promise to obtain a reward. The rest of this article entails a discussion of the mode of operation of piracy within both the Gulf of Guinea and the coast of Ghana with statistical data involving Ghana, Nigeria, Togo, and Benin. The article concludes with a theoretical framework and brief summary. 


\section{Modus Operandi of Piracy in the Gulf of Guinea and Coast of Ghana}

There are a high number of piracy attacks off the Gulf of Guinea and coast of Ghana and this rate is increasing. The modus operandi of piracy on the Gulf of Guinea include violence, especially because they utilise sophisticated weapons, such as AK-47s. Traditionally, off the Gulf of Guinea and coast of Ghana, the modus operandi of piracy includes speedboat use in order to "to attack and dispossess shipping crew of cash, cargo and valuable, when the vessel is anchor or in harbour, but mostly close to shore" [6]. Piracy within this area affects different West African countries, as well as international communities. An important area of concern is derived from the modus operandi of piracy in this area, where pirates are commonly associated with criminal enterprises that are heavily armed and use violence as a method for stealing oil cargo [7].

During the first decade of the century, piracy within the Gulf of Guinea and off the coast of Ghana has evolved due to the increased aggression and use of more effective weaponry. In 2014, it was noted that most piracy attacks occurred in territorial waters, including harbours and terminals, as opposed to the open sea. Because of this modus operandi, it has been difficult for international forces to intervene in the incidents. Since pirates in this area are part of an organised criminal enterprise, they are commonly well-funded, including supply networks that have already been established [7]. Moreover, due to the involvement of an organised criminal enterprise, pirates commonly launch attacks from motherships to steal oil cargo. This modus operandi shows that there is little importance to hostage situations of crew, vessels, or non-oil cargo for ransom. However, it is not uncommon for pirates to show their extremely violent modus operandi, which leads to kidnapping, torturing, injuring, and murder of ship crews as a way to intimidate shipping companies [8].

\section{Acts of Piracy-Coast of Ghana}

Table 1 shows the number of piracy attacks on the coast of Ghana, percentage of the whole, mean, variance, standard deviation, and coefficient of variation.

This is shown in Figure 1 (based on Table 1).

The methods and mode of operation of the pirates keep changing as efforts by the regional coast guard and navies step up their Maritime Security patrols. In areas where there is no significant show of force by the navies, the acts of piracy have been minimal or non-existent. The pirates shift to very vulnerable areas and launch their attacks as and when it is necessary and the presence of Maritime Security is felt. This accounts tor the inconsistencies in the number of piracy attacks along the Ghana, Benin, Togo and Nigeria coastal waters (Table 2).

It is noted that the most attacks occurred in 2008, 2014, and 2016. It is also noted that in 2010 , there were no attacks on this area. On average, the standard deviation is $0.74(74 \%)$ of the mean, indicating high variation between the data points. 
Table 1. Coast of Ghana descriptive statistics.

\begin{tabular}{ccccccc}
\hline Year & $\begin{array}{c}\text { Number of } \\
\text { Attacks }^{1}\end{array}$ & Percent & Mean & Variance & $\begin{array}{c}\text { Standard } \\
\text { Deviation }\end{array}$ & $\begin{array}{c}\text { Coefficient } \\
\text { of Variation }\end{array}$ \\
\hline 2007 & 1 & $4.00 \%$ & & 2.25 & 1.50 & 0.60 \\
2008 & 7 & $28.00 \%$ & & 20.25 & 4.50 & 1.80 \\
2009 & 3 & $12.00 \%$ & 0.25 & 0.50 & 0.20 \\
2010 & 0 & $0.00 \%$ & & 6.25 & 2.50 & 1.00 \\
2011 & 2 & $8.00 \%$ & 2.5 & 0.25 & 0.50 & 0.20 \\
2012 & 2 & $8.00 \%$ & & 0.25 & 0.50 & 0.20 \\
2013 & 1 & $4.00 \%$ & & 2.25 & 1.50 & 0.60 \\
2014 & 4 & $16.00 \%$ & & 2.25 & 1.50 & 0.60 \\
2015 & 2 & $8.00 \%$ & & 0.25 & 0.50 & 0.20 \\
2016 & 3 & $12.00 \%$ & & 0.25 & 0.50 & 0.20 \\
Sum & 25 & & Average & 3.45 & 1.86 & 0.74 \\
\hline
\end{tabular}

Source: Author's compilation from [9] [10] [11]. 'References: (International Maritime Bureau, 2010, 2015, 2016).

Table 2. Trend of Piracy cases in Somalia and Gulf of Aden 2003-2008.

\begin{tabular}{ccccccc}
\hline Location & 2003 & 2004 & 2005 & 2006 & 2007 & 2008 \\
\hline Somalia & 3 & 2 & 35 & 10 & 31 & 19 \\
Gulf of Aden/Red Sea & 18 & 8 & 10 & 10 & 13 & 92 \\
Other & 424 & 319 & 231 & 219 & 219 & 182 \\
Total at year end & 445 & 329 & 276 & 239 & 263 & 293 \\
\hline
\end{tabular}

Source: Author's compilation from [24].

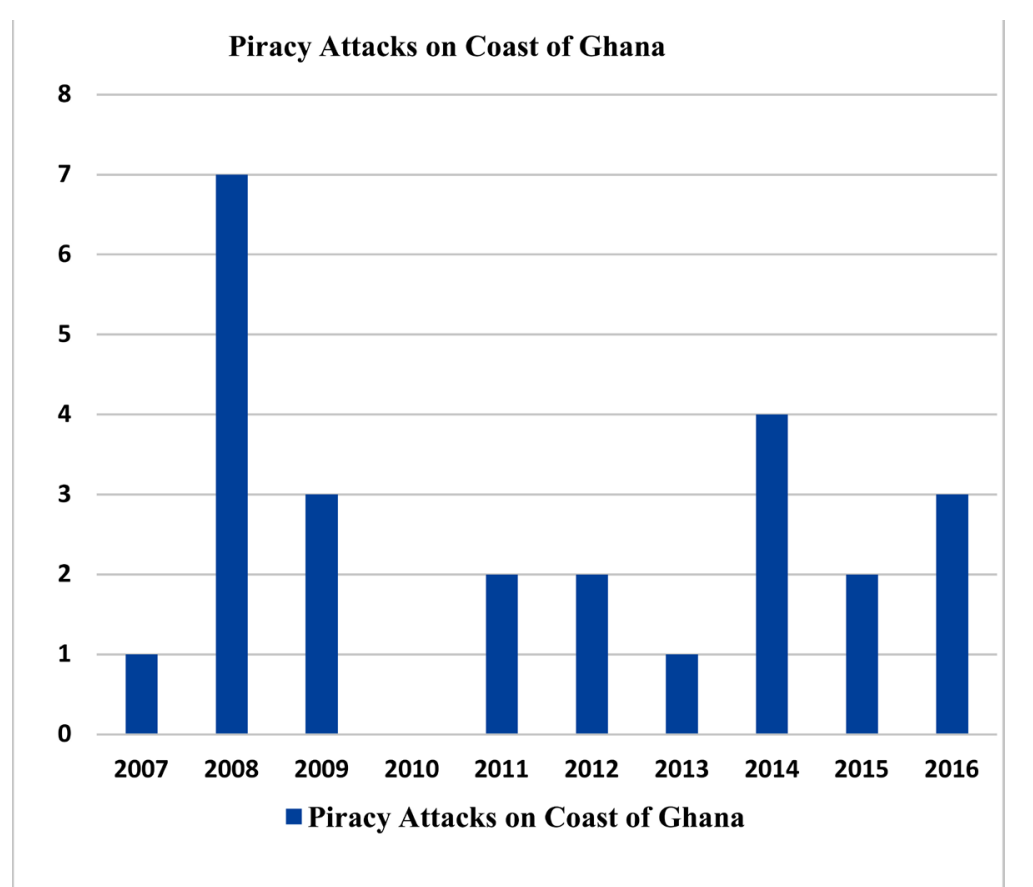

Figure 1. Piracy attacks on the Coast of Ghana. Source: Authors' compilation from [9] [10] [11]. 


\section{Acts of Piracy-Coast of Nigeria}

\section{Nigeria}

Table 3 shows the number of piracy attacks on Nigeria, percentage of the whole, mean, variance, standard deviation, and coefficient of variation.

This is shown in Figure 2 (based on Table 3).

It is noted that the most attacks occurred in 2007, 2008, and 2016. It is also noted that the fewest attacks occurred in 2012. On average, the standard deviation is $0.39(39 \%)$ of the mean, indicating moderate variation between the data points.

\section{Acts of Piracy-Coast of Togo}

This is shown in Figure 3 (based on Table 4).

Table 3. Coast of Nigeria statistics of pirate attacks.

\begin{tabular}{|c|c|c|c|c|c|c|}
\hline Year & $\begin{array}{c}\text { Number of } \\
\text { Attacks }^{2}\end{array}$ & Percent & Mean & Variance & $\begin{array}{l}\text { Standard } \\
\text { Deviation }\end{array}$ & $\begin{array}{l}\text { Coefficient } \\
\text { of Variation }\end{array}$ \\
\hline 2007 & 42 & $15.79 \%$ & \multirow{10}{*}{26.6} & 237.16 & 15.40 & 0.58 \\
\hline 2008 & 40 & $15.04 \%$ & & 179.56 & 13.40 & 0.50 \\
\hline 2009 & 29 & $10.90 \%$ & & 5.76 & 2.40 & 0.09 \\
\hline 2010 & 19 & $7.14 \%$ & & 57.76 & 7.60 & 0.29 \\
\hline 2011 & 10 & $3.76 \%$ & & 275.56 & 16.60 & 0.62 \\
\hline 2012 & 27 & $10.15 \%$ & & 0.16 & 0.40 & 0.02 \\
\hline 2013 & 31 & $11.65 \%$ & & 19.36 & 4.40 & 0.17 \\
\hline 2014 & 18 & $6.77 \%$ & & 73.96 & 8.60 & 0.32 \\
\hline 2015 & 14 & $5.26 \%$ & & 158.76 & 12.60 & 0.47 \\
\hline 2016 & 36 & $13.53 \%$ & & 88.36 & 9.40 & 0.35 \\
\hline Sum & 266 & & Average & 109.64 & 10.47 & 0.39 \\
\hline
\end{tabular}

Source: author's compilation from [9] [10] [11].

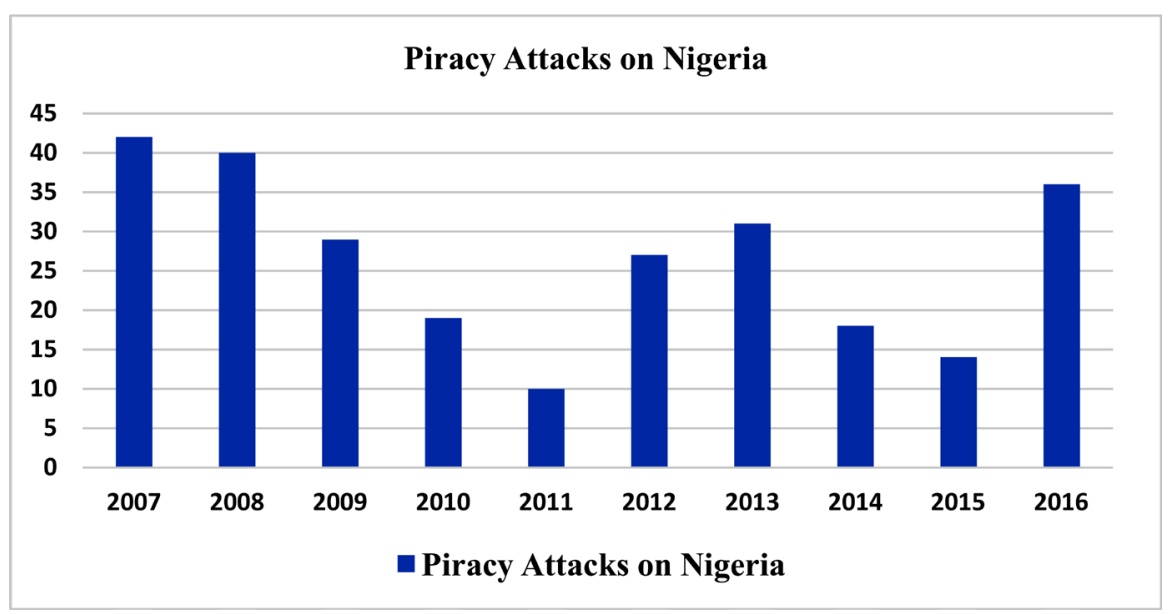

Figure 2. Piracy attacks on Nigeria. Source: Authors' compilation from [9] [10] [11]. 
Table 4. Coast of Togo descriptive statistics.

\begin{tabular}{ccccccc}
\hline Year & $\begin{array}{c}\text { Number of } \\
\text { Attacks }\end{array}$ & Percent & Mean & Variance & $\begin{array}{c}\text { Standard } \\
\text { Deviation }\end{array}$ & $\begin{array}{c}\text { Coefficient } \\
\text { of Variation }\end{array}$ \\
\hline 2007 & 0 & $0.00 \%$ & & 7.84 & 2.80 & 1.00 \\
2008 & 1 & $3.57 \%$ & & 3.24 & 1.80 & 0.64 \\
2009 & 2 & $7.14 \%$ & & 0.64 & 0.80 & 0.29 \\
2010 & 0 & $0.00 \%$ & & 7.84 & 2.80 & 1.00 \\
2011 & 0 & $0.00 \%$ & & 7.84 & 2.80 & 1.00 \\
2012 & 15 & $53.57 \%$ & 2.8 & 148.84 & 12.20 & 4.36 \\
2013 & 7 & $25.00 \%$ & & 17.64 & 4.20 & 1.50 \\
2014 & 2 & $7.14 \%$ & & 0.64 & 0.80 & 0.29 \\
2015 & 0 & $0.00 \%$ & & 7.84 & 2.80 & 1.00 \\
2016 & 1 & $3.57 \%$ & & 3.24 & 1.80 & 0.64 \\
Sum & 28 & & Average & 20.56 & 4.53 & 1.62 \\
\hline
\end{tabular}

${ }^{1}$ Source: Author's compilation from [9] [10] [11].

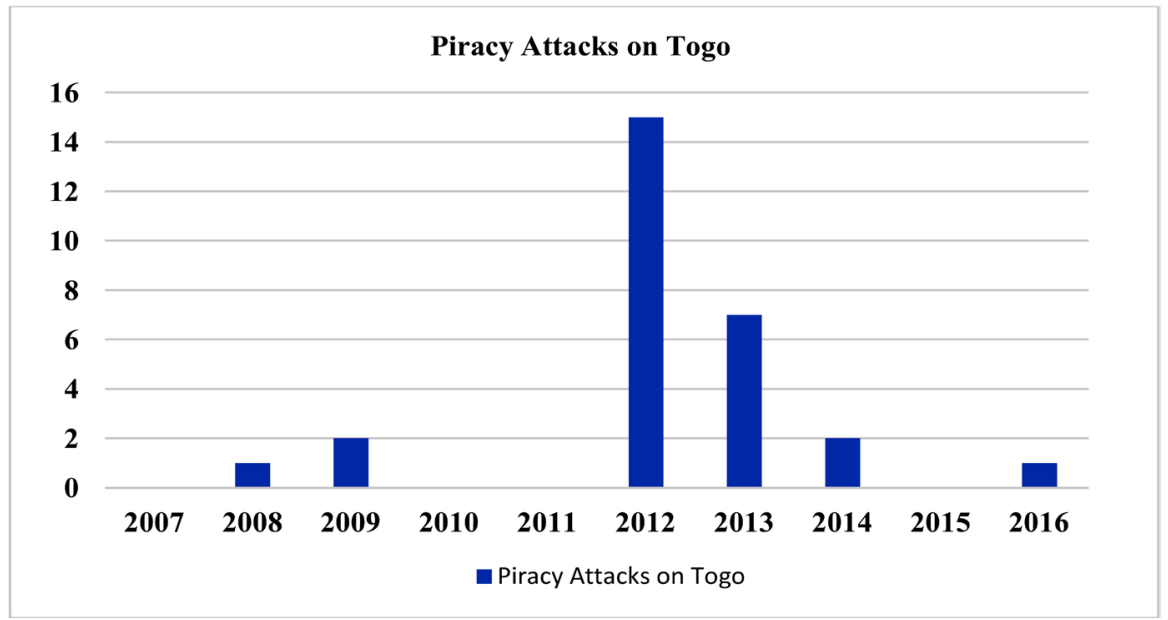

Figure 3. Pirate attacks on Togo. Source: Author's compilation from [9] [10] [11].

It is noted that the most attacks occurred in 2012. It is also noted that the no attacks occurred in 2007, 2010, 2011, and 2015. On average, the standard deviation is $1.62(162 \%)$ of the mean, indicating high variation between the data points.

\section{Acts of Piracy-Coast of Benin}

Table 5 shows the number of piracy attacks on Benin, percentage of the whole, mean, variance, standard deviation, and coefficient of variation.

This is shown in Figure 4 (based on Table 5).

It is noted that the most attacks occurred in 2011. It is also noted that the no attacks occurred in 2007, 2008, 2010, 2013, 2014, and 2015. On average, the standard deviation is 2.46 (246\%) of the mean, indicating high variation between 
Table 5. Coast of Benin descriptive statistics.

\begin{tabular}{ccccccc}
\hline Year & $\begin{array}{c}\text { Number of } \\
\text { Attacks }^{1}\end{array}$ & Percent & Mean & Variance & $\begin{array}{c}\text { Standard } \\
\text { Deviation }\end{array}$ & $\begin{array}{c}\text { Coefficient } \\
\text { of Variation }\end{array}$ \\
\hline 2007 & 0 & $0.00 \%$ & 5.76 & 2.40 & 1.00 \\
2008 & 0 & $0.00 \%$ & 5.76 & 2.40 & 1.00 \\
2009 & 1 & $4.17 \%$ & 1.96 & 1.40 & 0.58 \\
2010 & 0 & $0.00 \%$ & & 5.76 & 2.40 & 1.00 \\
2011 & 20 & $83.33 \%$ & 2.4 & 309.76 & 17.60 & 7.33 \\
2012 & 2 & $8.33 \%$ & & 0.16 & 0.40 & 0.17 \\
2013 & 0 & $0.00 \%$ & & 5.76 & 2.40 & 1.00 \\
2014 & 0 & $0.00 \%$ & & 5.76 & 2.40 & 1.00 \\
2015 & 0 & $0.00 \%$ & & 5.76 & 2.40 & 1.00 \\
2016 & 1 & $4.17 \%$ & & 1.96 & 1.40 & 0.58 \\
Sum & 24 & & Average & 34.84 & 5.90 & 2.46 \\
\hline
\end{tabular}

${ }^{1}$ References: (International Maritime Bureau, 2010, 2015, 2016).

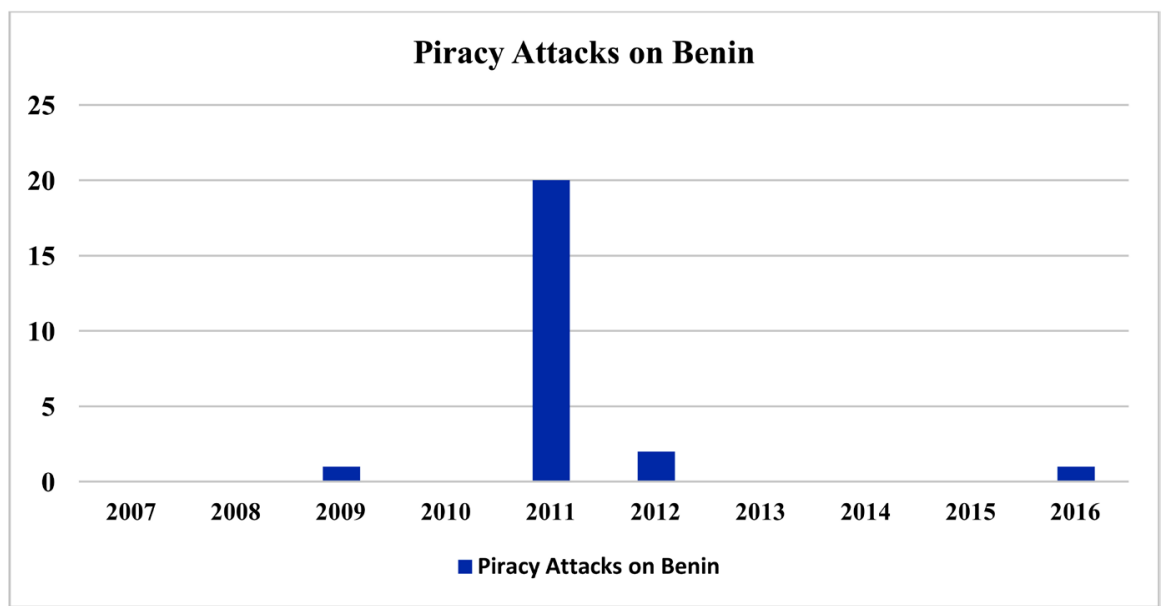

Figure 4. Piracy attacks on Benin. Source: Authors' compilation from [9] [10] [11].

the data points.

\section{Annual Totals of the Coast of Ghana, Nigeria, Togo, and Benin}

Figure 5 shows a comparison of the number of attacks for each country for the dataset (based on Table 1, Tables 3-5).

It was noted that Nigeria had the most attacks in all years except 2011. In 2011, Benin had the most attacks. In 2013, Togo had the most attacks, as compared to Nigeria. Table 6 shows the number of piracy attacks on for all countries (Coast of Ghana, Nigeria, Togo, and Benin) by year, percentage of the whole, mean, variance, standard deviation, and coefficient of variation.

This is shown in Figure 6 (based on Table 5). 
Table 6. All country descriptive statistics.

\begin{tabular}{ccccccc}
\hline Year & $\begin{array}{c}\text { Number of } \\
\text { Attacks }\end{array}$ & Percent & Mean & Variance & $\begin{array}{c}\text { Standard } \\
\text { Deviation }\end{array}$ & $\begin{array}{c}\text { Coefficient } \\
\text { of Variation }\end{array}$ \\
\hline 2007 & 43 & $12.32 \%$ & & 65.61 & 8.10 & 0.23 \\
2008 & 48 & $13.75 \%$ & & 171.61 & 13.10 & 0.38 \\
2009 & 35 & $10.03 \%$ & & 0.01 & 0.10 & 0.00 \\
2010 & 19 & $5.44 \%$ & & 252.81 & 15.90 & 0.46 \\
2011 & 38 & $10.89 \%$ & & 9.61 & 3.10 & 0.09 \\
2012 & 46 & $13.18 \%$ & 34.9 & 123.21 & 11.10 & 0.32 \\
2013 & 39 & $11.17 \%$ & & 16.81 & 4.10 & 0.12 \\
2014 & 24 & $6.88 \%$ & & 118.81 & 10.90 & 0.31 \\
2015 & 16 & $4.58 \%$ & & 357.21 & 18.90 & 0.54 \\
2016 & 41 & $11.75 \%$ & & 37.21 & 6.10 & 0.17 \\
Sum & 349 & & Average & 115.29 & 10.74 & 0.31 \\
\hline
\end{tabular}

${ }^{1}$ References: (International Maritime Bureau, 2010, 2015, 2016).

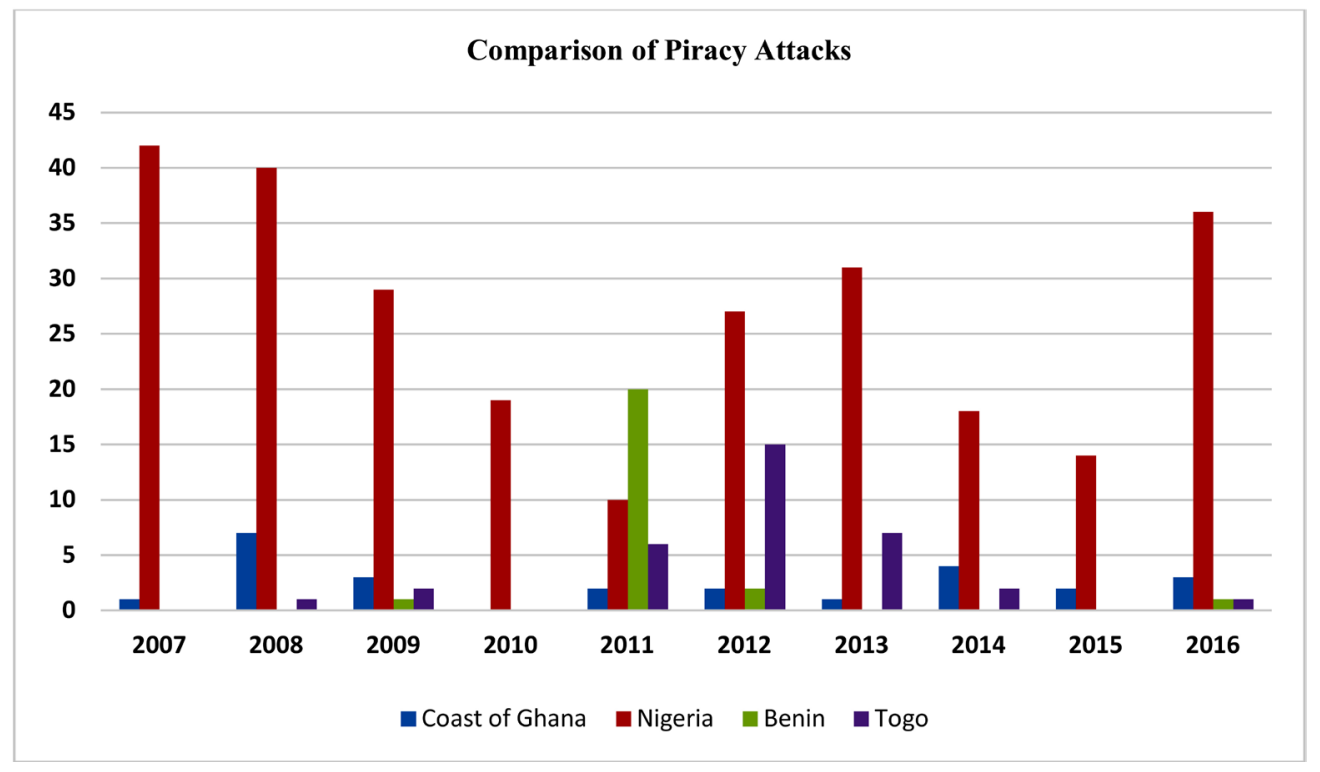

Figure 5. Piracy attacks. Source: Authors' compilation from [9] [10] [11].

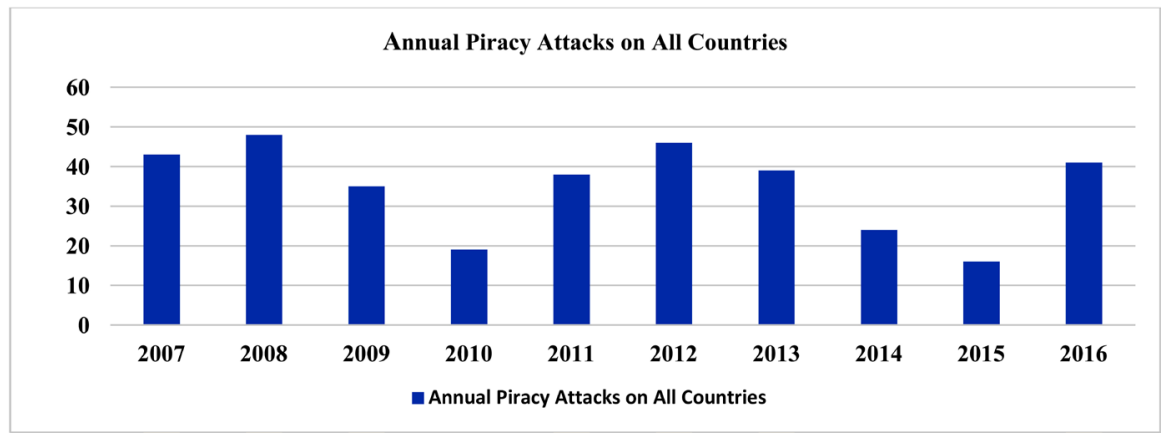

Figure 6. Piracy attacks. Source: Author's compilation from [9] [10] [11]. 


\section{Piracy Concerns}

It is noted that the most attacks occurred in 2008. It is also noted that the least attacks occurred in 2015. On average, the standard deviation is 0.31 (31\%) of the mean, indicating moderate variation between the data points.

Oceanic issues have for quite some time been dismissed in most African nations. While every single waterfront state on the mainland assert an Exclusive Economic Zone (EEZ) that extends to 200 nautical miles (370 kilometres) from the coastline, little exertion has been made to understand the sea's financial potential. As of late, be that as it may, the photo has begun to change [12]. Issues with robbery off Somalia and in the Gulf of Guinea are the most feature snatching marvel. All the more imperatively, privateer assaults have featured the difficulties related with an absence of security adrift. Unlawful angling, sneaking of medications and weapons or human trafficking could all have genuine consequences ashore. Seaward oil and gas generation offers immense open doors, yet can just occur in a pretty much secure condition. At last, oceanic exchange and, to a lesser degree, tourism are essential elements for future monetary development; once more, however, security adrift is a basic factor [12].

Automatic Identification System (AIS) has been made compulsory locally available on SOLAS vessels. Most Coastal States are as of now making courses of action to get, examine and follow up on AIS information [13]. As indicated by the IMO Performance Standard, AIS ought to enhance the security of route by aiding the...operation of Vessel Traffic Services (VTS). Be that as it may, the adequacy of AIS as a VTS instrument for activity administration and data benefit depends vigorously on the nature of AIS data and shrewd applications for data handling, mix, and introduction. The utilization of AIS suggests that GNSS and electronic graphs (ENC) have at long last begun to assume their parts in VTS. The examination of AIS execution as a VTS instrument depends on long haul consistent perceptions of genuine AIS messages around Keelung Harbour of Taiwan [13]. The Ghana Maritime Authority (GMA) has acquired a Vessel Traffic Management Information System (VTMIS) to assist in the surveillance of the Ghana coastline from any security threats and aid international shipping with maritime security information in that area.

Researchers contest that the inescapability of theft on the African coasts is undermining worldwide security. Inside Somalia, it is causing a disturbance of nourishment supplies, cultivating inner clash, and expanding the costs of essential wares [14]. All around, it is coordinating an emotional ascent in oceanic protection premiums and sea weakness, upsetting global business, expanding the likelihood of an ecological calamity, and empowering an anxious, rising association with psychological warfare. Robbery must be ceased. To accomplish this target, the researchers suggest redoing the universal law on robbery, keeping up sufficient beach front security along the problem areas on the African coasts, utilizing military power, setting up safe sea paths, preparing groups on safety efforts, positioning furnished protects on ships, and in particular, restoring politi- 
cal soundness in Somalia [14].

Both national and worldwide conduits are indispensably vital to states since they fill in as a medium of transportation, a wellspring of monetary misuse of such mineral assets as unrefined petroleum, and a wellspring of nourishment through angling and shrimp angling. Deplorably, Africa's waters now speak to one of the world's hazardous conduits for vessels and its group individuals as far as privateer assaults. This article concentrates on privateer exercises in Nigeria and Somali waters in Africa, basically in light of the fact that they have recorded the most astounding rates of privateer assaults over the most recent couple of years. It analyses the measurement sea theft has expected in these waters, talks about the components behind the new flood of privateer exercises, and unwinds the ramifications of sea robbery for human security in the landmass [15] [16] [17].

\section{Joint Military Exercises and the Role of China}

In December 2008, the naval force of the Peoples' Republic of China (People's Freedom Army Navy, or PLAN) sent a team, made up of two guided rocket destroyers and a supply dispatch, to partake in worldwide anti-piracy operations off the bank of Somalia, in the Gulf of Aden/Horn of Africa (HoA) district [18]. This organization denoted the first run through in current history that China's naval force has occupied with an operational mission outside of its asserted regional waters. The PLAN's cooperation in worldwide hostile to piracy operations has been seen by numerous in the United States and somewhere else as a sign of China's evident readiness to go up against a bigger military part on the worldwide stage [18].

On March 20, 2009, CNA China facilitated a half-day meeting to talk about China's response to the hostile robbery exercises. Bringing together United States authorities, investigators, and dynamic obligation military work force, the meeting considered the reasons that piracy has turned into an issue in the Gulf of Aden/HoA area; the drivers for China's phenomenal maritime investment in worldwide response to robbery endeavours; the suggestions that this interest has for China's naval force; and the potential ramifications that it has for the United States [18]. Eliminating piracy is, at last, a political difficulty as much as it is a military one. Members focused on that, while national militaries have a vital part to play in counteracting future privateer assaults and ceasing those effectively in progress, in the long haul the issue must be settled with an imbuement of solid political will. A few speakers faulted the tirelessness of privateer movement on the joined elements of Somalia's close aggregate shortage of local administration, the powerlessness or unwillingness of Somali control holders to bring known privateers to equity, and an absence of global agreement on the most proficient method to manage culprits [18].

At present, more than twelve countries have sent boats to watch the Gulf of Aden/Horn of Africa area. Some of these are taking part in Combined Task 
Forces 150 and 151 (CTF-150 and -151), under the multi-national Combined Maritime Forces (CMF). The EU, as well as NATO have likewise given their own consolidated oceanic errand gatherings to the district-these are not some portion of the CMF, but rather they do facilitate with it. Various different countries, counting Russia, China, India, and Malaysia, have sent maritime powers working under national entrusting to the locale to shield their vessels and teams from privateers. All things considered, one speaker stated, there are 14 maritime vessels watching the Gulf of Aden at any given time, in a blend of coalition and non-coalition powers [18].

China has not joined any coalition, and its expressed essential objective in conveying PLAN vessels is defending and giving security to Chinese vessels and staff cruising through the area. Although China has not joined a coalition, authorities from China's Ministry of National Defence (MND) have said that China will fortify insight and data trades and, when essential, partake in helpful alleviation operations with all nations, including the United States. MND authorities have likewise clarified that the choice to convey maritime vessels to the Gulf of Aden/Horn of Africa area was received on the premise of an UN determination, and that China advocates fortifying the initiative and coordination capacity of the United Nations in tending to piracy (Kaufman, 2009). China's cooperation in global action against piracy operations speaks to a noteworthy move both in the extent of its national security interests and in its obvious eagerness to go up against a bigger military part on the worldwide stage. Speakers examined a few derivations that could be drawn from China's exceptional cooperation in antipiracy operations. In the first place, they noted, China's readiness to send warships far outside its regional waters flags move in its meaning of its national security interests. Brought in conjunction with other official Chinese military and government explanations, experts induced, China's hostile to piracy operations might be viewed as some portion of a more drawn out term development toward entrusting the PLA and the PLAN with extended missions went for securing a more various arrangement of national interests that are not characterized by topography-including securing financial interests, avoiding psychological oppression, conveying compassionate guide, furthermore, directing other Military Operations Other Than War (MOOTW) [18].

Second, a few members proposed, China's exceptional participation with (despite the fact that no formal investment in) the CMF hostile to piracy teams shows a newly discovered eagerness to collaborate with different militaries and governments on issues of common concern. By appearing itself anxious to be viewed as a capable partner in settling worldwide issues, China might open the entryway for other agreeable endeavours later on. China's maritime collaboration in against piracy operations has, generally, been invited by the United States military [18]. Experts from an extensive variety of United States organizations communicated energy for the PLAN's cooperation in against piracy operations. China's readiness to keep up open correspondences and share data with the 
United States(also, more for the most part, with the CMF antipiracy team) has took into consideration uncommon every day correspondence between the strategic and operational levels of the two militaries, as opposed to the infrequent and abnormal state conciliatory stages on which military-to-military relations are typically directed. Speakers recognized that there were a few dangers related with nearer contact, and a few communicated reservations about whether China's naval force is increasing more from this contact than is the United States Naval force. Be that as it may, in general, the advantages of this nearer contact supposedly outweighed the potential costs [18].

\section{Oil and Piracy in the Gulf of Guinea}

Once suspected privateers have been caught, the forbidding state must figure out where the suspects ought to be exchanged for the examination and arraignment of their claimed wrongdoings. Despite the fact that robbery is an all inclusive wrongdoing, certain states-the banner express, the prohibiting state, the condition of nationality of the group or proprietor of the casualty vessel, or others-may have specific national interests in the examination and indictment of the suspects (Africa Center for Strategic Studies, 2015) [19]. At the same time, the prohibiting state likewise may have exchange agreements with different States who have communicated an ability to add to the global group's counter-theft endeavours by indicting caught suspects in their national courts. Given the potential complexities and the need to limit the length of confinement of suspects adrift, forbidding states may wish to have set up a system for making demeanour choices. The system underneath gives a case of such a basic leadership system. At each step, the system gives a course of events by which certain activities must be performed or certain choices must be taken keeping in mind the end goal to facilitate a definitive demeanour of the suspects [20].

Once the on-scene authority decides a potential for indictment exists, the prohibiting office gives fitting prohibiting state (IS) administrative experts (conciliatory, barrier, legal and law requirement) with an underlying report on the assault as quickly as time permits [21]. To the greatest degree conceivable, the report ought to contain the accompanying data: condition of registry of casualty sent; nationality of the group; kind of freight locally available; condition of nationality of the proprietor of the vessel; whether there were witnesses (casualty or military) and, assuming this is the case, roughly what number of; number and birthplace of the presumed privateers (if Somalia, indicate locale); depiction of the episode; and last and next ports of call of the casualty deliver [20].

In view of the underlying report, the law authorization specialists of the IS (in discussion with fitting law authorization, political, and protection, specialists) make a starting assurance in the matter of whether they plan to seek after an examination. This underlying assurance ought to be made as before long as conceivable in the wake of accepting the underlying report. Among different components, law requirement experts will consider national nexus to the assault, 
including whether the case included an assault on an IS-hailed vessel or a vessel claimed by an IS national or with IS nationals on board as well as the general enthusiasm of IS to indict the case at hand [22]. States ought to set up the fundamental interior frameworks to manage such circumstances and additionally the applicable techniques, including fitting time limits for each progression. On the off chance that law requirement experts choose to seek after indictment in the IS, continue with Option A. In the event that law authorization specialists decrease to seek after indictment in the IS, continue with Option B. The choices might be sought after all the while to spare time [23].

\section{Conclusions}

It has been broadly perceived globally that present structures on a residential, provincial, and global level are not satisfactory at checking oceanic theft, nor are they bound together in their way to deal with address current robbery. Oceanic robbery significantly affects tourism, sending, and assembling businesses, provoking governments to infer that sea theft is a major issue since it impacts security and wellbeing [1]. In any case, in opposition to a few recommendations, oceanic theft assaults are not generally irregular occasions and frequencies may increment in light of the kind of vessel and banner of registry [2].

Sea theft has impacted worldwide financial improvement, as appeared on account of Somalia. Through demonstrating the delivery requests and volumes of transportation, which require re-steering, prompting effectiveness misfortune [4] have demonstrated that there is a significant monetary misfortune because of sea theft. In addition, there are immediate expenses to the prompt robbery casualties, where teams might be harmed or executed; boats and cargoes might be stolen; and organizations may encounter higher working expenses and higher protection costs. The roundabout expenses of theft are additionally huge, particularly in connection to compassionate contemplations. For instance, if a ship containing payload for a philanthropic gathering is commandeered and its load is stolen, for example, alleviation items, the casualties stretch out to incorporate those that would have profited from the arrangement of help required for survival, (for example, nourishment). Accordingly, on account of Somalia and Nigeria, living conditions, which are now delicate because of the neediness of the locales, are compounded by robbery [5]. The Maritime Organization of West and Central Africa (MOWCA) which seeks to foster cooperation among West and Central African states should ensure the member states become more vigilant in Maritime Security. The United States African Command (AFRICOM) should assist the various regional groups in fighting the menace of piracy in the Gulf of Guinea (GoG). The Economic Commission of West African States (ECOWAS) members should join ranks and share vessel security information and data bases. The International Criminal police (INTERPOL) should assist by coordinating with the regional security agencies and share data and security information. 


\section{References}

[1] Bento, L. (2011) Toward an International Law of Piracy Sui Generis: How the Dual Nature of Maritime Piracy Law Enables Piracy to Flourish. Berkeley Journal of International Law, 29, 399-745.

[2] Mejia, M.Q., Cariou, P. and Wolff, F.-C. (2009) Is Maritime Piracy Random? Applied Economics Letters, 16, 891-895. https://doi.org/10.1080/13504850701222186

[3] Chalk, P. (2009) Maritime Piracy: Reasons, Dangers and Solutions. https://trid.trb.org/view.aspx?id=968732

[4] Fu, X., Ng, A.K.Y. and Lau, Y.-Y. (2010) The Impacts of Maritime Piracy on Global Economic Development: The Case of Somalia. Maritime Policy \& Management, 37, 677-697. https://doi.org/10.1080/03088839.2010.524736

[5] Nincic, D. (2009) Maritime Piracy in Africa: The Humanitarian Dimension. African Security Review, 18, 1-16. https://doi.org/10.1080/10246029.2009.9627538

[6] Onuoha, F.C. (2012b) Piracy and Maritime Security in the Gulf of Guinea: Nigeria as a Microcosm.

[7] Kamal-Deen, A. (2015) The Anatomy of Gulf of Guinea Piracy. Naval War College Review, 68, 93-119.

[8] Barker, S. (2013) International Maritime Piracy: An Old Profession That Is Capable of New Tricks, But Change Is Possible. Case Western Reserve Journal of International Law, 46, 387.

[9] International Maritime Bureau (2010) Piracy and Armed Robbery against Ships: Annual Report.

[10] International Maritime Bureau (2015) Piracy and Armed Robbery against Ships.

[11] International Maritime Bureau (2016) Piracy and Armed Robbery against Ships.

[12] Siebels, D. (2014) Maritime Security in Africa: Potential for the Private Sector? Conflict Trends, 19-26.

[13] Chang, S.J. (2004) Development and Analysis of AIS Applications as an Efficient Tool for Vessel Traffic Service. In: Oceans 04 MTS/IEEE Techno-Ocean 04 (IEEE Cat. No.04CH37600), Vol. 4, IEEE, 2249-2253. https://doi.org/10.1109/OCEANS.2004.1406499

[14] Anyu, J.N. and Moki, S. (2009) Africa: The Piracy Hot Spot and Its Implications for Global Security. Mediterranean Quarterly, 20, 95-121. https://doi.org/10.1215/10474552-2009-017

[15] Onuoha, F.C. (2009) Sea Piracy and Maritime Security in the Horn of Africa: The Somali Coast and Gulf of Aden in Perspective. African Security Review, 18, 31-44. https://doi.org/10.1080/10246029.2009.9627540

[16] Onuoha, F.C. (2009) Violence at Sea: The Ramifications of Maritime Piracy in Nigerian and Somali Waters for Human Security in Africa. Institute of African Studies Research Review, 25, 21-44.

[17] Onuoha, F.C. (2012) Oil Piracy in the Gulf of Guinea. Conflict Trends, 2012, 28-35.

[18] Kaufman, A.A. (2009) China's Participation in Anti-Piracy Operations off the Horn of Africa: Drivers and Implications.

[19] Africa Center for Strategic Studies (2015) Maritime Security in the Gulf of Guinea.

[20] Wambua, P.M. (2009) Enhancing Regional Maritime Cooperation in Africa: The Planned End State. African Security Review, 18, 45-59. https://doi.org/10.1080/10246029.2009.9627541 
[21] Osinowo, A.A. (2015) Combating Piracy in the Gulf of Guinea.

[22] Vreÿ, F. (2009) Bad Order at Sea: From the Gulf of Aden to the Gulf of Guinea. African Security Review, 18, 17-30. https://doi.org/10.1080/10246029.2009.9627539

[23] Neethling, T. (2010) Piracy around Africa's West and East Coasts: A Comparative Political Perspective. Scientia Militaria: South African Journal of Military Studies, 38, 89-108.

[24] Ocean Policy Research Foundation (2009) OPRF MARINT Monthly Report. 22.

[25] Tepp, E. (2012) The Gulf of Guinea: Mulitary and Non-Military Ways of Combating Piracy. Baltic Security \& Defense Review, 14, 181-214. 